\title{
The implications of oil pollution for the enjoyment of sexual and reproductive rights of women in Niger Delta area of Nigeria
}

\author{
Olubayo Oluduro and Ebenezer Durojaye
}

\begin{abstract}
Oil is a major source of income for Nigeria and it is the mainstay of the country's economy. Nigeria's intensive oil sector accounts for nearly $40 \%$ of its gross domestic product, but declined steadily to an average of $14.71 \%$ of the country's total export between 2006 and 2011; and contributed about $80 \%$ of budgetary revenues that all tiers of government heavily depend on. ${ }^{2}$ Oil spills and gas flaring are some of the effects of the unregulated exploratory activities of the oil multinational companies that have contributed immensely to the physical and mental illness of the local inhabitants of the Niger Delta region and violated most of their rights as guaranteed under international and regional human rights instruments and the Constitution of the Federal Republic of Nigeria 1999 (as amended) 1999. In view of the growing threats to human health and the environment (posed by human activities), the international community has agreed to a number of treaties to respond to the health and human rights challenges posed by environmental degradation. Although Nigeria is a party to most of these instruments, 3 it has done little or nothing to regulate the conduct of the oil companies that negatively impact on the health of the Niger Delta people. While the impact of oil extraction affects both men and women, the article focuses on its implications for women's reproductive well-being. This is because women are a disadvantaged and marginalised group and have continued to experience discriminatory practices in many parts of the country, including the Niger Delta area. The article discusses the health challenges associated with oil exploitation in the Niger Delta, paying attention to the position of women. It then proffers suggestions on measures and steps that could be taken by the Nigerian government and other stakeholders in ensuring the adequate protection of the health rights of local inhabitants.
\end{abstract}

\section{Introduction}

The Niger Delta region is located in the southern part of Nigeria. It covers over 70,000 square kilometres and is made up of nine states (Abia, Akwa Ibom, Bayelsa, Cross River, Delta, Edo, Imo, Ondo and Rivers) out of the 36 states that make up Nigeria. ${ }^{4}$ The region is one of the largest wetlands in the world, with the ecosystem being acknowledged as one of the most diverse and richest in the world. The crude oil and natural gas deposits in Nigeria are concentrated in the Niger Delta, thus making the region a point of attraction for the multinational oil companies (MNCs). Presently, there are over 400 oil and gas 
production and storage facilities and several oil pipelines criss-crossing the entire region with its challenges on ecosystem sustainability ${ }^{5}$ and the health of the people. The intensive exploitation of the Niger Delta area's rich oil reserves right from the discovery of oil at Oloibiri (now Bayelsa State) in 1956 has had some adverse effects on the region's environment. This article highlights the health challenges associated with oil exploitation in the Niger Delta, paying attention to its implications for women's sexual and reproductive well-being. It examines international human rights instruments and domestic laws on health and environment, and discusses whether the Nigerian government has lived up to its obligations under these instruments and laws, particularly regarding the protection of the right to health of women in the Niger Delta region. Finally, it offers some suggestions on what could be done by all stakeholders in the Nigerian oil industry towards ensuring the adequate protection of the health of local inhabitants.

\section{The health implications of oil exploitation in the Niger Delta}

Oil exploitation has brought immense wealth to Nigeria, but this has happened at the expense of the social and economic well-being of the people of Niger Delta. This section of the article examines some activities associated with oil exploitation that often endanger the society.

\subsection{Oil spills}

The incidence of oil spills arising from pipelines (which criss-cross the communities), pipeline vandalisation, blowouts at well-heads, the wastes and refinery effluents discharged, or the construction of flow stations near communities, have contributed to pollution and severe health problems in the region, and have led to the destruction of the mangrove forests and extermination of aquatic lives. More importantly, oil spills have resulted in the pollution of water in the Niger Delta area. Given that the Niger Delta area consists of riverine villages where people's lives are dependent on water, oil pollution is likely to pose some grave health hazards to the people. This situation is disturbing in view of the reliance of the Niger Delta people on coastal forests for sustenance. Virtually every area of their lives, including the economic, social and natural environment, has been affected by the activities of the oil MNCs. The innumerable creeks and streams in the region have in the past provided a habitat for an abundance of fish and marine life. ${ }^{6}$ These serve as a means of livelihood for the majority of the people in the Niger Delta since they depend on the resources of the wetlands for their food. Mangroves and other resources derived from the seascape are to the people what taxes are to the governments. ${ }^{7}$

Wetlands are generally sensitive environments, because the soil soaks up the oil like a sponge and then releases it afresh every rainy season. ${ }^{8}$ The oil film in water prevents natural aeration and destroys fish and other aquatic animals. At the same time, endangered species, such as white monkeys, river hippopotamus, the Delta elephant and crocodiles are fast disappearing because of the activities of the oil MNCs. The Niger Delta, which was once one of the 10 most important and productive wetland and marine ecosystems in the world, has been described as 'one of the 5 most severely petroleum-damaged ecosystems and oil polluted environments in the world'. 9 '

\section{http://repository.uwc.ac.za}


A study conducted in Ogoniland in the Niger Delta area has revealed the nature and extent of oil pollution in the area. For instance, the study reveals contamination of drinking water by benzene at levels over 900 times the level prescribed by the World Health Organization (WHO).$^{10}$ This study reveals contamination of water taken from 28 wells at 10 communities adjacent to contaminated sites. Samples taken from about seven wells indicate that the level of hydrocarbons is about 1000 times higher than the Nigerian drinking water standard of 3 micrograms per liter (mg/l). ${ }^{11}$ This could result in deleterious health consequences for the people of Niger Delta area.

\subsection{Gas flaring}

Gas flaring entails burning off the natural gas associated with the crude oil during extraction in places where there is no capacity or infrastructure to trap and make use of the gas. It is a process by which unusable or excess natural gas is released by a pressure valve and burned releasing tonnes of carbon dioxide into the atmosphere. One of the major causes of ill health in the Niger Delta, particularly among women, is uncontrollable gas flaring and gas leakages. This produces soot, laden with harmful chemicals including hydrocarbons, sulphurous oxides and the oxides of Nitrogen, which negatively affect soil fertility and which have also been linked with many ailments, including bronchial, chest, rheumatic and eye problems. ${ }^{12}$ The continued flaring of gas on a daily basis in the Niger Delta area exposes the people, particularly women and children, to grave health hazards. It is believed that gas flaring in Nigeria has contributed larger volumes of green-house gases than all of subSaharan Africa combined, as well as releasing several dangerous toxins into the atmosphere, polluting the soil and affecting the health and well-being of the nearby Niger Delta communities. It also exposes the residents to an increased risk of premature death, respiratory illnesses such as asthma, and cancer. The flaring of associated gas during oil production often results in emissions including particulate matter (smoke), sulphur and nitrogen oxides, benz[a]pyrene and dioxin and unburned fuel components such as toluene, benzene and xylene. These components are believed to be poisonous and may lead to significant health problems such as asthma, coughing and difficulty in breathing, chronic bronchitis and possibly premature death. The US Environmental Protection Agency (EPA) has noted that exposure to benzene and its metabolites can cause acute non-lymphocytic leukaemia and a variety of other blood-related disorders in humans. ${ }^{13}$

\section{The link between oil exploitation and women's reproductive well-being in the Niger Delta}

The link between health and oil pollution has long been recognised, ${ }^{14}$ but the impact of oil pollution on individuals cannot be generalised. No doubt, while the impact of oil exploitation affects both men and women, including children, evidence abounds that women and children are often worst affected. It is important to bear in mind that oil exploitation can have direct and indirect consequences for women's health and reproductive well-being. The environmental and health impacts of oil exploitation in the Niger Delta are often considerable, horrible and negative and are particularly borne by the women because of their

\section{http://repository.uwc.ac.za}


biology. They conceive, carry pregnancy, give birth to and breastfeed children and these actions expose them to a lot of environmental problems arising from oil exploitation.

In addition to their biology, women in the Niger Delta tend to experience more environmental hazards from oil exploitation than men because they tend to engage in menial activities such as farming and fishing. This is based on the patriarchal nature of African society. Patriarchy has been defined as 'a system of interrelated social structures through which men exploit women.. .The key sets of patriarchal relations are to be found in domestic work, paid work, the state and male violence and sexuality, while other practices in civil society have a limited significance.' ${ }^{\prime 5}$ This would seem to apply to most parts of Nigeria, including the Niger Delta area. A study has shown discriminatory cultural practices such as widowhood rites, denial of inheritance rights and exclusion from decision-making. These in turn have contributed to the poor living conditions of women in the Niger Delta area. ${ }^{16}$

Besides, women in these communities are usually the food providers, major income earners and caregivers for the family. Therefore, they engage in various hard jobs to provide the means for family survival - food, water and energy. In the event of an environmental degradation caused by the activities of the MNCs, as is often the case in the Niger Delta region, women are usually the primary victims because of their profound dependence on, and their more frequent and intimate contact with nature, compared to their male counterparts. ${ }^{17}$ As noted earlier, women engage in menial activities such as farming and work in proximity to oil industry operations, therefore becoming more likely to be exposed to environmental hazards that can negatively affect their health and ability to provide care for their families. Thus, the above could be explained in terms of women's inherent biological connection, their roles at home, and their mutual devaluation and domination within patriarchal ideology. ${ }^{18}$ Indeed, 'the female body is very different from the male body, both physically and biologically and pertinently in one specific aspect the female body can fall pregnant and thus become two persons that must be considered, the mother and the baby with very specific risk factors' ${ }^{19}$ For example, long-term exposure to vibrations may increase the risk of miscarriage and stillbirth, prolonged exposure to noise can elevate the blood pressure of pregnant women and carbon monoxide can result in the foetus being starved of oxygen. ${ }^{20}$ Thus, any work that exposes an individual to physical, chemical, ergonomical or biological hazards must be considered potentially dangerous to the health of women. ${ }^{21}$ Whilst a considerable benefit is derived through the exploitation of oil by the Nigerian government and the oil MNCs, suffice to say that for each gain there are several negative externalities or 'disbenefits' ${ }^{\prime 2}$ to the local inhabitants of the region, particularly the women. This clearly explains why women are more exposed to the harm of pollution than their male counterparts.

Some studies have shown that poverty is more prevalent among women in the Niger Delta area compared to their male counterparts. ${ }^{23}$ It has further been shown that due to high unemployment and poverty levels in the region, young girls sometimes trade sex for money or other benefits. This tends not only to compromise their health but also lead to

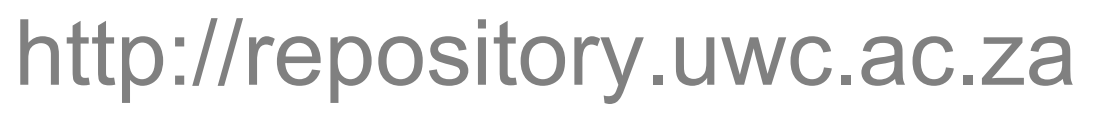


unwanted pregnancies and incidences of sexually transmitted infections. ${ }^{24}$ This situation is vividly captured in the novel Yellow-Yellow by Kaine Agary. ${ }^{25}$ The novel is the story of an illicit relationship between an 18-year-old Ijaw girl (Ina Binaebi) and a Greek sailor. The result is an early pregnancy and Binaebi's ambition to get a good job is truncated. This tends to reflect the plight of many young school leavers in the Niger Delta region and this also accounts for the ever-growing number of half-caste children in the oil rich region today. It has been noted that in some parts of the Niger Delta children are fathered by Europeans, British, Portuguese, Syrians, Lebanese, Filipinos, Chinese and Americans who come to do business in the region. ${ }^{26}$

\section{The health implications of oil exploitation for Niger Delta women \\ 4.1 International and regional instruments relating to women and the environment}

In discussing the implications of oil exploitation on the enjoyment of women's reproductive health and well-being, it is important to understand in detail the nexus between the right to health and a healthy environment. There are several international and regional instruments and consensus statements linking environment with the health of women. Some of these instruments and consensus statements are discussed below.

The right to health is guaranteed in numerous international and regional human rights instruments. The most authoritative of these is Article 12 of the International Covenant on Economic, Social and Cultural Rights (ICESCR), ${ }^{27}$ which guarantees the right of everyone to the enjoyment of the highest attainable standard of health. The Committee on Economic, Social and Cultural Rights (CESCR) has explained that the right to health guaranteed under the covenant is inclusive and must embrace the determinants of the right to health such as, food, housing, potable water and a healthy environment. ${ }^{28}$ It also explains that the right to health intersects with other important rights such as life, dignity, nondiscrimination and privacy. The committee has further noted that the right to health must be guaranteed to all, particularly vulnerable and marginalised groups such as women, children and people with disabilities. ${ }^{29}$ A recent resolution adopted by the United Nations General Assembly expresses the link between health and environment, stating that 'all individuals are entitled to live in an environment adequate for their health and wellbeing. ${ }^{30}$

Other instruments that have guaranteed the right to health include Article 12 of the Convention on Elimination of All Forms of Discrimination against Women (CEDAW) and Article 24 of the Convention on the Rights of the Child (CRC). ${ }^{31}$ The CEDAW Committee in its General Recommendation $24^{32}$ has explained that the right to health of women includes ensuring that women have unhindered access to the health care services needed for their well-being and refraining from interfering in services that are peculiar to the needs of women. The Committee further requires states to take appropriate measures to ensure adequate living conditions for women, particularly housing, water supply, electricity and a healthy environment.

\section{http://repository.uwc.ac.za}


At the regional level, the African Charter on Human and Peoples' Rights in its Article 24 provides that 'All peoples shall have the right to a general satisfactory environment favourable to their development.' Also, Article 16 of the Charter provides for the right of every individual to enjoy the best attainable state of physical and mental health and calls on states parties to take all the necessary measures to protect the health of their people and to ensure that they receive medical attention when they are sick. ${ }^{33}$ Relying on Articles 16 and 24 of the African Charter, two non-governmental organisations (NGOs) brought a complaint before the African Commission on behalf of the Ogoni people (Niger Delta people). ${ }^{34}$ The complainants alleged in their communication among others that the oil consortium had exploited oil reserves in Ogoniland with no regard for the health or environment of the local communities, disposing toxic wastes into the environment and local waterways in violation of applicable international environmental standards. It further alleged that the consortium also neglected and/or failed to maintain its facilities causing numerous avoidable spills in the proximity of villages. The resulting contamination of water, soil and air has had serious short and long-term health impacts, including skin infections, gastrointestinal and respiratory ailments, and increased the risk of cancers, and neurological and reproductive problems. ${ }^{35}$

The Commission found the Nigerian government to have violated the provisions of Articles 16 and 24 of the African Charter which obligate it to desist from directly threatening the health and environment of its citizens. It found that while the Nigerian government has the right to produce oil, it must take proper care in ensuring that it does not violate people's (Ogoni people's) rights to health and live in a safe and clean environment. ${ }^{36}$

Furthermore, Article 14 of the Protocol to the African Charter on the Rights of Women (African Women's Protocol) contains important and progressive provisions relating to the right to health and sexual and reproductive health of women. Also, the Protocol provides in Article 18 that 'Women shall have the right to live in a healthy and sustainable environment.' It further enjoins states parties to take all appropriate measures to 'ensure greater participation of women in the planning, management and preservation of the environment and the sustainable use of natural resources at all levels' ${ }^{37}$ and 'ensure that the negative effects of globalisation and any adverse effects of the implementation of trade and economic policies and programmes are reduced to the minimum for women'. ${ }^{38}$

In addition to these international instruments, there are other declarations and commitments by states relating to women and the environment. The Beijing Platform of Action states that:

The deterioration of natural resources displaces communities, especially women, from income- generating activities...environmental degradation results in negative effects on the health, well-being and quality of life of the population at large, especially girls and women of all ages. Particular attention and recognition should be given to the role and special

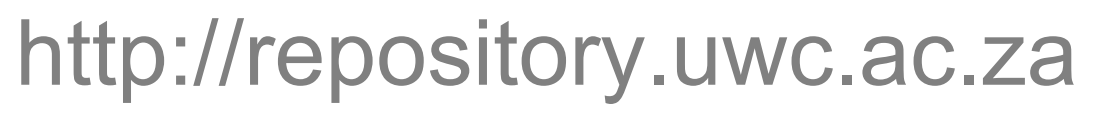


situation of women living in rural areas and those working in the agricultural sector,.. .Environmental risks in the home and workplace may have a disproportionate impact on women's health because of women's different susceptibilities to the toxic effects of various chemicals. These risks to women's health are particularly high in urban areas, as well as in low-income areas where there is a high concentration of polluting industrial facilities. 39

Also, Agenda 21 of United Nations Conference on Environment and Development (UNCED) in Rio, 1992, emphasised the need to establish mechanisms at the national, regional and international levels to assess the implementation and impact of development and environmental policies and programmes on women and to ensure their contributions and benefits. It enjoined countries, including Nigeria, to carry out research on the impact on women of environmental degradation, the structural linkages between gender relations, environment and development, and to ensure that women are fully involved in decisionmaking and in the implementation of sustainable development activities. ${ }^{40}$ While the decisions reached at this conference are not binding on states, they impose moral obligations on states to ensure that they take appropriate measures to safeguard the environment.

The implication of the above international instruments and declarations is that the threat of oil exploitation and environmental degradation to the health and livelihood of the local inhabitants of the Niger Delta, particularly the women, is not only a local issue but also a global concern. These continued violations of human rights, particularly with regard to environmental degradation, in the name of development, may constitute a grave barrier to the realisation of the Millennium Development Goals (MDGs). In view of the provisions of the above regional and international instruments on the link between environment and women's health, and the African Commission's decision, it behoves the Nigerian government to be more responsive to the impact of oil exploitation and other developmental projects on the environment, human rights and health of the people, particularly the women.

It should be noted that Nigeria has ratified most of the international human rights instruments mentioned above and as such is obligated to ensure the full realisation of the provisions of these instruments. The discussion below will show the various dimensions and implications of oil exploitation for women's reproductive rights and well-being. The focus will be on direct and indirect consequences of oil exploitation on women's reproductive health and wellbeing.

\subsection{Direct consequences}

(i) Pollution and access to water and sanitation: The 2010 report by the WHO/UNICEF Joint Monitoring Programme for Water Supply and Sanitation (JMP) revealed that out of Nigeria's estimated population of 151 million, about 65 million people still lack access to water that is safe to use. The report further revealed that as of 2008 , only about $42 \%$ of the rural population in Nigeria had access to a supply of improved drinking water..$^{41}$ The report

\section{http://repository.uwc.ac.za}


further indicates that Nigeria is one of the countries that is not on track to meet the MDG target on water and sanitation. Given the poor number of people having access to safe drinking water, the situation is likely to be aggravated by oil pollution in the Niger Delta area. Indeed, the situation in the Niger Delta region is disturbing as local inhabitants lack access to a potable water supply due mainly to oil pollution. A sachet of water (usually not pure) which ordinarily sells for N5.00 in other parts of Nigeria goes for N20.00 in many of the communities in the Niger Delta because of the acute water shortage caused by oil pollution. Unfortunately, some of the sachet water sold to the people is poorly packaged and not hygienic enough for consumption. This tends to put the health and life of the people at risk. Thus, the people are torn between not having access to water due to pollution or resorting to buying unsafe sachet water. Between 76 and $80 \%$ in rural areas and 50 and $55 \%$ in urban areas do not have access to safe drinking water ${ }^{42}$ in the Niger Delta area. Since the available water sources are increasingly being polluted by the toxicity of crude oil, women thus resort to the use of unsafe and polluted water for domestic uses. These sources are known to harbour the snail vectors for schistosomiasis (Bilharzia) and other pathogens and bacteria, of which studies have shown that women and children are high risk groups. ${ }^{43}$ Residents in the Niger Delta region interviewed by Human Rights Watch not only complained that spills in their area had made people, especially children, who drank the water sick, but also that fish often taste of paraffin (kerosene), indicating hydrocarbon contamination. ${ }^{44}$ In many communities near oil installations (even in the absence of a recent spill), an oily sheen can be seen on the water, which poses a danger to the health of the people given that this same water is used for drinking and washing. ${ }^{45}$

In April 1997, samples taken from water used for drinking and washing by local villagers were analysed in the USA. A sample from Luawii, in Ogoni, where there had been no oil production for four years, had $18 \mathrm{ppm}$ of hydrocarbons in the water, 360 times the level allowed in drinking water in the European Union (EU). A sample from Ukpeleide, Ikwerre, contained $34 \mathrm{ppm}, 680$ times the EU standard. ${ }^{46}$ This was confirmed by the UNEP Report 2011 where, for example, the sample taken from Nsisioken Agbi in Eleme Local Government Area of Rivers State showed the presence of free-Phase hydrocarbon in water used for drinking, cooking and washing, with a very high concentration of benzene (a known carcinogen), methane and methyl tertiary butyl ether (MTBE), meaning that there is a high risk to the community of benzene, methane and MTBE poisoning from water used for drinking. ${ }^{47}$ There may only be a 'little difference between a State that arbitrarily executes persons and a State that knowingly allows water to be poisoned by contaminants. ${ }^{48}$ In both situations, the state may be held liable for depriving individuals of the right to life, particularly where there is evidence linking the loss of lives to failure of the state to take appropriate measures to prevent oil pollution. Recent developments regarding the interpretation of the right to life would seem to require states not only to refrain from interfering with the enjoyment of this right, but also to take appropriate steps to prevent loss of lives. ${ }^{49}$

\section{http://repository.uwc.ac.za}


With water sources close to their homesteads polluted, women have to travel farther distances, on average 4-10 kilometres, in search of alternative sources, particularly where the community do not have a borehole or are not close to another community where there is a borehole..$^{0}$ More often, they go with their children in search of water or to fetch firewood for domestic use, which they have to carry on their heads with the potential to cause serious health effects such as neck, back and leg injuries, cranial depression and severe headaches, pelvic and spinal deformities and osteoarthritis of the knees. ${ }^{51}$ Sometimes they are exposed to the risk of sexual assault or harassment by men when walking along lonely and dangerous roads to get water. ${ }^{2}$ At present, some oil MNCs have started to intervene by digging boreholes in some of the host communities through their community development programmes in order to ensure an adequate water supply for the people. But this is like a drop of water in the ocean and is insufficient to address the deprivations experienced by the people of this area. Prior to the commencement of oil exploration activities in this region, there was an abundant good water supply and women did not need to travel long distances to get good water for family use.

In addition, polluted water often leads to a lack of proper sanitation for the people. This is because the communities rely heavily on water for proper sanitation. Communities lacking adequate supplies of freshwater and basic sanitation carry the highest burdens of disease, which disproportionately impact women and children under five years of age. ${ }^{53}$ The implications of this can be very grave for women who may be forced to defecate in open places. This can expose women and girls to various forms of sexual abuse and assault. Studies have shown that women are often the subject of sexual abuse where they lack access to proper and private sanitation. ${ }^{54}$ The United Nations General Assembly has affirmed access to water and sanitation as a human right and urges state members to take adequate steps towards removing obstacles to access to water and sanitation for the most vulnerable and marginalised groups. In addition, the then UN independent expert on the issue of human rights obligations in relation to water and sanitation has noted that for many women and girls lack of access to water and sanitation can result in loss of dignity and lead to insecurity. ${ }^{55}$ Similarly, the UN Special Rapporteur on water and sanitation has noted that human rights violations as a result of lack of access to clean water and sanitation can have more serious consequences for women than men..$^{56}$

In spite of the negative impacts of oil pollution in the Niger Delta, neither the Nigerian government nor the oil companies have really appreciated the enormity of these problems in order to develop appropriate programmes to address the health implications of their activities on the communities, particularly the most vulnerable group such as women and children. This implies that this vulnerability of women and children to the environmental hazards caused by oil exploitation may likely persist for a long time to come with the attendant consequences on their health. Thus, women and children are now faced with 'exposure to external shocks, stress and risks' from oil exploitation activities. At the same time, they seem defenceless in the hands of the oil MNCs that do not care about protecting the environment, which serves as a source of livelihood for the rural communities. ${ }^{57}$

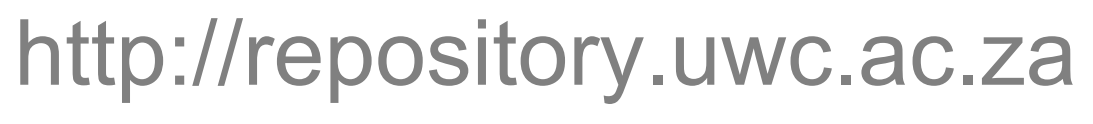


(ii) Food production and health: The health impacts of air pollution, largely due to gas flaring, spread across a wide area, and all those who rely on locally produced food - whether from their own production or bought at the market - risk contamination. ${ }^{8}$ It is common in the Niger Delta to see women at the flare sites using the toxic flames to dry their food items and fish, which the oil companies have regarded as economic benefits to the local inhabitants. ${ }^{59}$ In doing this, women are exposed to high levels of pollution from the sites, unaware of the health implications of such. These may include sulphur dioxide, nitrogen dioxide, as well as carcinogenic substances such as benz[a]pyrene, dioxin, benzene and toluene, which may impact negatively on the health and physiology of the local inhabitants and affects the environment. ${ }^{60}$ The Environmental Rights Action and the Climate Justice Programme in a study carried out in 2005 attempted to assess the harm done by the toxic cocktail of pollutants, including benzene and dioxins, produced by gas flaring. It is estimated that in Bayelsa State alone, flaring is likely to cause 49 premature deaths, 4960 child respiratory illnesses, 120,000 asthma attacks and eight additional cases of cancer each year. ${ }^{61}$ In another study carried out in Rivers State between May 2007 and January 2008 by Gobo et al. ${ }^{62}$ on the impact of flared gases on human health using the Igwuruta/Umuechem communities (with a history of gas flaring) and the Ayama community (with no history of gas flaring), it was found that there is a correlation between environmental variables resulting from gas flaring and the development of certain ailments found in individuals residing in such an area. According to the authors, 'Health conditions such as asthma, cough, breathing difficulty, eye irritation and dizziness which are commonly associated with air pollution occur more frequently in Igwuruta/Umuechem area than in Ayama and accounted for $22.4 \%$ of all cases recorded at lgwuruta health centre, and this is almost a quadruple of that for the Abua/Odual axis with $5.9 \%$ of recorded cases according to available records. ${ }^{63}$ The resultant adverse effects of gas flaring include premature deaths, respiratory illnesses, asthma, blood disorders, cancer and others. ${ }^{64}$

(iii) Climate change and health: Flaring in Nigeria contributes a great deal to Africa's emission of greenhouse gases, leads to climate change, creates acid rain, retards crop yields, corrodes roofs, and so on. The Nigerian gas alone produces 35 million tons of $\mathrm{CO}_{2}$ and 12 million tons of methane, more than the rest of the world. ${ }^{65}$ It has been shown that women are more likely to experience health problems arising from climate changerelated disasters than men. For instance, it was reported that in the European heat wave in 2003, $75 \%$ more women than men died due to factors including poverty, deprivation, vulnerability to associated air pollution, and the fact that women above 60 years of age have increased problems in regulating their internal temperature, hence becoming more vulnerable to dehydration. ${ }^{66}$ This is a clear indication that women, particularly those in their reproductive age, are susceptible to health hazards as a result of gas flaring. More importantly, the consequences of gas flaring can be graver for pregnant women than other members of society given their vulnerability to other infections. Gas flaring may not only constitute a threat to a pregnant woman but it also exposes the unborn child to grave health consequences, including mortality.

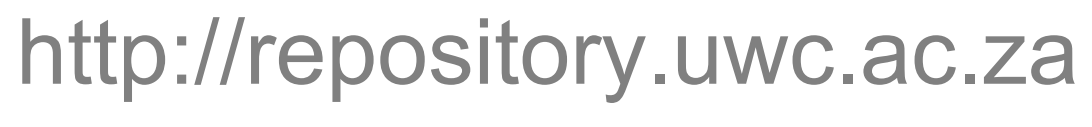


(iv) Oil exploitation and reproductive health: Oil exploitation increases the risks associated with the reproductive rights of women. This is because 'women's societal roles and lifestyle choices can result in environmental exposures different from those of men and because some unique biologic characteristics of women can cause physiologic responses to a given exposure that differ from those of men'. ${ }^{67}$ The combined effect of persistently drinking contaminated water and inhaling noxious fumes from gas flaring will not only have an impact on the health of the women in the region but may threaten the growth and mental development of their foetuses. ${ }^{68}$ These occur as a result of the predisposition to peculiar diseases in communities where oil exploration takes place, coupled with poor antenatal care and malnutrition, thus making the lives of pregnant women in these communities particularly precarious. ${ }^{69}$ Apart from being predisposed to giving birth to children with defects, Hurtig and Sebastiá $n$ have noted that women living in the proximity of oil fields have 2.5 times higher risk of spontaneous abortion than other women..$^{70}$ For example, in Ecuador, oil exploration activities by ChevronTexaco from 1964-1992 was found to have led to an exploding health crisis, including cancer, reproductive problems and birth defects in communities close to the oil reserves. ${ }^{71}$ Because of the differences in their physiologic responses to environmental issues, the women in the Niger Delta are likely to be carrying in their bodies several noxious chemicals that were unknown to their grandparents which may negatively impact even the unborn. The new-born baby who reaches for her mother's breast receives heavily contaminated food from her mother's milk, which is heavily laden with toxic substances and would not meet food guidelines..$^{72}$

\subsection{Indirect consequences}

This part of the article examines the indirect implications of oil exploitation for the enjoyment of women's fundamental rights.

(i) Sexual violence and assault: Women and girls in the Niger Delta suffer most in resource conflicts in Nigeria. They have been subjected to various inhuman and degrading treatments, particularly rape and different forms of sexual slavery, at the hands of Nigerian security personnel usually sent on peace missions to the region, including those deployed to guard oil flow stations. For example, it was reported that following a demonstration by youths in Choba against a pipeline construction company called Wilbros Nigeria Ltd (a subsidiary of Wilbros Group, a US company) on 28 October 1999, the military personnel that invaded Choba unleashed a reign of terror on the community. Rape and sexual abuse of women in the Niger Delta area by military personnel have been well-documented and published in the Nigerian daily press. ${ }^{73}$ In November 1993 the women in Ogoniland were sexually harassed, assaulted and battered by the military personnel. The women described in detail in interviews with members of the Federation of Ogoni Women's Organisations (FOWA) the sexual violence they experienced at the hands of Nigerian Military personnel purportedly on a peace mission in their community. For example, one woman reported:

One day we were demonstrating. We sang as we moved from our town to Ken Khana. Singing near the main road we met face to face with the army... they asked us to lie down on the road.

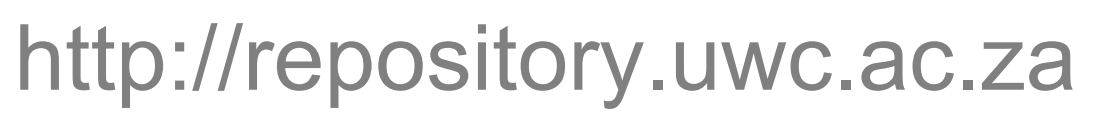


After using the koboko (whip) on us they started kicking us with their foot. They dragged some of the women into the bush. We were naked, our dresses were torn, our wrappers were being loosed by a man who is not your husband. They tore our pants and began raping us in the bush. The raping wasn't secret because about two people are raping you there. They are raping you in front of your sister. They are raping your sister in front of your mother. It was like a market. 74

More than 50 allegations of rape by the security forces in Odi in 1999 were recorded by Women's Aid Collective (WACOL). ${ }^{75}$ In Ugborodo, Delta State, women were also allegedly raped by the security personnel during a demonstration in February 2002, in protest against the perceived failure of Chevron Nigeria Ltd to implement a memorandum of understanding between it and the community of Ugborodo. The affected women reported that soldiers used guns to rape them: 'The women were stripped naked while guns were pointed into their private parts. ${ }^{76}$ In places like Congo, where the crisis rages on over the natural resources located in the country, the incidences of rape have reached an epidemic level. It is estimated that 40 rapes occur every day in one province alone, and $60 \%$ of fighters are believed to be HIV-positive. ${ }^{77}$

The consequences of sexual violence range from physical injuries to potential sexually transmitted diseases (including HIV/AIDS), miscarriages, forced and unwanted pregnancy, single parenting, physical and psychological scars, and traumatic fistula - debilitating tears in the tissue of the vagina, bladder and rectum. ${ }^{78}$ Besides this, it also results in stigma as women are avoided by their spouses, relatives and communities and suffer long-term reproductive health consequences. However, the responses of the Nigerian government to all these violations of the sexual rights and fundamental freedoms of the Niger Delta women - perpetrated by agents of the state in collaboration with the oil companies have been inadequate as they have failed to investigate these heinous crimes and bring the culprits to justice. ${ }^{79}$ Government cannot claim ignorance as most of these crimes are not only reported in the media but some of the victims' interviews are shown on national television. Such insensitivities on the part of the government to the plight of the women further confirm little regard for the human rights of the local inhabitants in the Niger Delta.

From the above, it can be seen that the military personnel sent on peace missions to the Niger Delta have reportedly used rape as an instrument to intimidate, humiliate and terrorise the local inhabitants and to get revenge for attacks on oil installations by the militants. The Constitution of the Federal Republic of Nigeria, 1999, under section 34(1) provides that: 'Every individual is entitled to respect for the dignity of his person, and accordingly, (a) no person shall be subjected to torture, or to inhuman or degrading treatment.' In addition, section $17(2)$ (b) states that '. . . human dignity shall be maintained and enhanced'. Though, these provisions of the Constitution do not explicitly prohibit rape and other sexual violence, they can be used to deal with offences of this nature. Besides, the Nigerian Criminal Code $^{80}$ (applicable in the southern part of the country) and the Penal Code ${ }^{81}$ (applicable in the northern part of the country) make rape a criminal offence punishable by imprisonment.

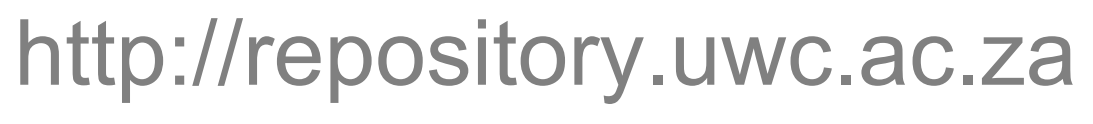


The Protocol to the African Charter on Human and Peoples' Rights on the Rights of Women in Africa, ${ }^{82}$ ratified by Nigeria on 18 February 2005, provides in Article 3 for the right to dignity. Article 4, dealing with the right to life, integrity and security of the person, states that 'Every woman shall be entitled to respect for her life and the integrity and security of her person. All forms of exploitation, cruel, inhuman or degrading punishment and treatment shall be prohibited.' It requires states to enact and enforce laws to prohibit, prevent and punish 'all forms of violence against women including unwanted or forced sex whether the violence takes place in private or public'. ${ }^{83}$ Article 4 further obligates states to 'prohibit and condemn all forms of harmful practices which negatively affect the human rights of women and which are contrary to recognised international standards' ${ }^{84}$ Rape constitutes torture, as defined by Article 1 of the International Convention against Torture and Other Cruel, Inhuman, or Degrading Treatment or Punishment. ${ }^{85}$ It also violates the prohibitions against torture in Article 7 of the International Covenant on Civil and Political Rights. ${ }^{86}$ The cruel nature of sexual violations in conflict zones have led to the adoption of Resolution 1820 in June 2008 by the United Nations Security Council, a resolution which calls for the classification of rape as a weapon of war. ${ }^{87}$

It should be noted that the African Commission applied the principle of due diligence in the SERAC case to hold that the Nigerian government was in violation of the rights to health, dignity, non-discrimination and healthy environment guaranteed under the charter for its failure or inability to control the activities of MNCs in the Niger Delta area. This approach will seem to coincide with the position of the CEDAW Committee in its General Recommendation 19 on Violence against Women, where the committee states that a state will be held responsible for acts of violence against women occasioned by a third party if the state fails to take necessary measures to protect women from such acts of violence. Therefore, failure of the Nigerian government to take effective measures to prevent rape and to prosecute those soldiers who committed rape will amount to violations of women's rights as guaranteed under international and regional human rights instruments.

The Oputa Panel was set up by the Nigerian government to investigate human rights violations (between 15 January 1966 and 29 May 1999) by the security forces, among others. During the public hearings, the panel documented experiences of victims, including women, who had been raped by members of the Nigerian security personnel, and their families. The report of the panel, which was submitted to the Federal Government in May 2002 is yet to be made fully public and none of the victims has been compensated, even more than 11 years later. ${ }^{88}$ The failure of the Nigerian government to take effective measures to prevent rape and to prosecute those soldiers who committed rape constitute violations of Articles 2 and 4 of the International Convention Against Torture. Having failed to exercise due diligence to prevent, stop, investigate, prosecute those soldiers who committed the rapes and provide reparations for the victims, ${ }^{89}$ it is submitted that the Nigerian government may be held accountable for violating the Nigerian Constitution, Articles 2 and 4 of the International Convention Against Torture, Article 5 of the UN Code of Conduct for Law

\section{http://repository.uwc.ac.za}


Enforcement Officials ${ }^{90}$ and the other international human rights instruments as discussed above.

(iii) Sociocultural impact of oil and health: Another important effect of oil exploitation in the Niger Delta is its sociocultural impact on the local communities, particularly the women. The negative effects of the oil exploitation on the means of livelihood of the local communities (farming/fishing) have resulted in the rise of commercial sex work in the region. Describing the impact of the activities of Chevron on their community, a member of the Escravos Women's Coalition observes that 'Our farms are all gone, due to Chevron's pollution of our water. We used to farm cassava, okro, pepper and others. Now all the places we've farmed are sinking, we cannot farm. We cannot kill fishes and crayfish. ${ }^{91}$ As a result of the dislodgement of the economic base of the women in the Niger Delta region, they are left with little or no alternative than to trade their bodies for survival, which increases their vulnerability to HIV/AIDS infection. Evidence from the Ante-natal Clinic survey carried out in 2008 revealed that HIV/AIDS pandemic is still on the increase in the Niger Delta region with the incidence in three of the Niger Delta region States - Akwabom (9.7\%), Cross River (8.0\%) and Rivers (7.3\%) - exceeding the national average of $4.6 \%$ for the country. ${ }^{92}$ The business of the oil industry has brought about a mass influx of people into the Niger Delta. Commercial sex work and other risky sexual behaviours and lifestyles became a lucrative business in the region as a result of the influx of foreign oil workers who earn a lot as expatriates. More importantly, some of the oil workers tend to work for a considerable number of weeks far away from their wives and engage in sexual relationships with locals or sex workers, thereby getting exposed to HIV infections. ${ }^{93}$ The situation is even more precarious for rural women in the communities who are unable to negotiate safer sexual practices. ${ }^{94}$ Sexually transmitted infections, including HIV/AIDS, may undermine and compromise the health and well-being of women, thereby interfering with the enjoyment of their highest attainable standard of physical and mental health. The high rate of commercial sex work may also lead to an increase in teenage mothers with fatherless children.

The CEDAW Committee has noted that states are under an obligation to ensure that they take appropriate measures to prevent women from resorting to sex work as a means of livelihood. The Committee has also enjoined states to ensure that they adopt appropriate policies that will improve the economic conditions of women and thus prevent them from all forms of abuse. ${ }^{95}$ In one of its Concluding Observations to the government of Nigeria, the committee expressed concerns regarding high rates of poverty and unemployment among women in the country, particularly in the Niger Delta area. The committee thus calls on the government of Nigeria to take necessary measures to address this concern. ${ }^{96}$ This requires that the Nigerian government must wake up to its responsibilities and obligations under international and regional human rights instruments and ensure that the rights of women of the Niger Delta are adequately protected. 
(iv) Medicinal plants and women's health: The negative impacts of oil exploitation in the oil producing communities of the Niger Delta also have the potential to destroy the healthseeking behaviour of the local communities, ${ }^{97}$ particularly the rural women who rely on medicinal plants for their health purposes. The Niger Delta region alone holds $60-80 \%$ of all Nigerian plant and animal species..$^{98}$ Some of the native plants and animals found in the Niger Delta are used for medicinal purposes. Not less than 22 plant species are used by the local inhabitants for medicine, and these include cinochona species, digitalis species, acacias, and so on. ${ }^{99}$ About 50,000-70,000 plant species are used in medicines, of which 15,000 are threatened. ${ }^{100}$ Owing to inadequate medical personnel and poor health facilities in the local communities in the Niger Delta, most of these medicinal plants are used by traditional birth attendants. The heat the flares generate kills vegetation around the flare area, destroys medicinal plants, mangroves and swamps, and suppresses the growth and the flowering of some plants. ${ }^{101}$ The exploration activities right from the clearing of the land to the construction of the pipelines results in the destruction of the medicinal plants found in this region. The environmental pollution associated with oil exploitation in the form of oil spills and gas flaring has serious implications on these medicinal plants and other species found in the Niger Delta. This is more vividly captured by Pyagbara in the following words:

During oil spills, the process of photosynthesis which enhances plant diversity is impaired since the process is reduced due to the fact that spilled crude have a high absorbance property so when the crude spreads onto the surface of leaves, the latter find it difficult to photosynthesize and thus die, leading to biodiversity loss. The toxic crude also affects underground herbs and shrubs, while microbial organisms which form important groups in the food web, are also destroyed. ${ }^{102}$

\section{The way forward}

(i) Provision of quality health: The environmental hazards caused by oil exploitation have serious health repercussions for the local inhabitants of the Niger Delta, particularly for women. Calls for urgent intervention by the government and an increase in the government's allocation of health resources in the region are imperative. The Nigerian health system is grossly under-funded, with government expenditure on health hovering around $4-5 \%$ of the total annual budget. ${ }^{103}$ The situation is even worse in the Niger Delta region where it is revealed that there is only one doctor for every 150,000 residents. ${ }^{104}$ Following the military assault on the Gbaramatu Kingdom in Delta State in May 2009, about 3000 women and their children became refugees for months at a health facility in Ogbe Ijoh. ${ }^{105}$ The same health facility again became a home for displaced local people of the Ayakoromor community, Delta State, during a military operation by Nigerian soldiers. That the health facility became a refugee home is a clear indication of the jaundiced development efforts in the region. If this facility were to be functioning as a hospital, as it was meant to be, would it readily turn into a refugee camp? ${ }^{106}$ The few available health care facilities are widely dispersed and, in the difficult swamp environment of the core Niger Delta, thereby making travelling to where they are difficult and time-consuming undertaking. ${ }^{107}$ All of the above make the cost of health care

\section{http://repository.uwc.ac.za}


services in the community highly prohibitive and usually out of the reach of the poor, particularly women. As a result, the local inhabitants patronise unqualified but locally available care providers, with little or no control by the government. Unfortunately, some of the untrained professionals in order to cut costs may use unsterilised needles for intravenous injections. Also, traditional healers often consulted by locals may use unsterilised sharp objects like blades and knives for incisions on their clients, in order to heal them of their diseases, for safe delivery or to protect them from diabolical attacks. ${ }^{108}$ All of these exacerbate the already weak health systems in the region and pose danger to the health and well-being of the people, particularly women.

Government must ensure the establishment of functional community based health services that are fully equipped with necessary facilities and personnel, which are capable of providing easy access to quality health for the people in the region. More importantly, the Nigerian government must increase budgetary allocation to the health sector in general and the Niger Delta in particular, in line with its commitments during the Abuja Declaration. The Nigerian government must monitor the activities of MNCs in the Niger Delta in order to protect its citizens. In addition, the government must ensure that appropriate measures are taken to address the gender dimension of oil exploitation in the Niger Delta. In this regard, the government must establish a legal framework based on respect for women's rights, so that every woman knows her baby will grow up in a world that is safer, healthier, and where the woman can breast feed her baby without fear. ${ }^{109}$

(ii) Women's involvement in environmental issues: Although women are negatively impacted by the environmental degradation through their productive and reproductive roles, oil MNCs tend to marginalize them in their various discussions with the communities on ways of addressing the damage to the environment. ${ }^{110}$ This may not be unconnected with the fact that the community leaders, who are usually males, are presented as the spokespersons of the communities. ${ }^{111}$ Even in situations where women approach the oil companies directly to raise issues of direct concern to them, the companies are always hesitant to deal directly with them. ${ }^{112}$ At the national level, where laws and policies regarding environmental issues are made, or where decisions on such are taken, women have less say as they are underrepresented in political and business circles where issues of vital importance are discussed. Currently, only a few of the Nigerian members of the National Assembly are female, thus showing that a smaller proportion of their interests may be taken into account in decision-making relating to laws and policies on natural resource exploitation. For instance, at the 1999 national election, there were three female senators out of 109 (2.8\%) and 12 female members of the House of Representatives out of 360 (3.3\%). In 2003, for female senators, the number remained three, while that of House of Representatives increased almost twofold to $23(6.4 \%) .{ }^{113}$ Evidence from developed countries with higher levels of female representation in politics showed an outstanding successful reduction in their carbon dioxide emissions, indicating that an improved gender balance and the furtherance of gender equality would help to reduce greenhouse gas emissions. ${ }^{14}$ However, despite promises and even court judgments to stop gas flaring in Nigeria, ${ }^{115}$ the oil companies

\section{http://repository.uwc.ac.za}


have continued to flare gas and little or nothing is being done by the government to address the situation in the form of effective laws and policies. This may be attributed to the limited numbers of women holding political power.

There is a need for the Nigerian government to mainstream gender into political and business spheres in the same way like some Scandinavian countries and also ensure the abrogation of policies and practices that enforce gendered roles. ${ }^{116}$ In many of these countries, women have continued to enjoy equal opportunities to participate in political and economic spheres of life. Gender equality policies and programmes have been adopted to ensure that women and men enjoy the same opportunities, rights and obligations in all areas of life. In most of these countries, the overarching principles have been that everyone, regardless of gender, has the right to work and support themselves, to balance career and family life, and to live without the fear of abuse or violence. Gender equality implies not only equal distribution between men and women in all domains of society. It is also about the qualitative aspects, ensuring that the knowledge and experience of both men and women are used to promote progress in all aspects of society. This has led to improved living conditions not only for women in these countries but in society as a whole. The Global Gender Gap Report of 2012 ranked Sweden as one of the leading countries in terms of achieving gender equality. ${ }^{117}$ This is an important message to the Nigerian government to reiterate the fact that when women are given equal opportunities to participate in decision-making and economic development society is the better for it.

(iii) Women empowerment: Given their susceptibility to the negative consequences of oil pollution, women are important stakeholders in any decision or negotiation to improve the situation. Experience has shown that women do possess great expertise in all fields of human endeavours similar to their male counterparts. However, due to patriarchy, women's expertise in society is hardly recognised or valued. Involvement of women as important stakeholders in decision-making would not only lead to better and more accepted decisions, but may also improve the living conditions of women. Empowerment and training of women on issues affecting their sexual and reproductive health, including the effect of environmental hazards, should be encouraged continually as this can lead to positive outcomes. For example, training courses are conducted in Vietnam on toxic chemicals and contamination especially for women farmers, and gender commitments related to Multilateral Environmental Agreements (MEAs) are implemented through national health laws in the Czech Republic and Luxemburg. ${ }^{118}$ Once women are better informed, they are able to play an active role in environmental issues, which in turn impacts positively on their health and general well-being.

Also, there is a need to address discriminatory practices against women in the areas of land ownership and inheritance laws, which usually strip women of ownership of property, thus exposing them to poverty. Furthermore, as a way of addressing gender inequalities, the Nigerian government must embark on gender awareness campaigns to sensitise policymakers at different levels of government. Where necessary, the government will need to

\section{http://repository.uwc.ac.za}


abolish harmful cultural practices or laws that discriminate against women. In addition, decision-makers must ensure that gender mainstreaming is incorporated as an important strategy in the process of policy formulation. ${ }^{119}$ In February 2005, the 23rd session of the UNEP Governing Council/Global Ministerial Environment Forum adopted decision 23/11 on gender equality in the field of the environment ${ }^{120}$; women's empowerment and the enhancement of women's leadership in the environmental sector are some of the major objectives of their decision. The Council agreed to promote women's participation in environmental decision-making, adopt a gendered balance and participatory development approach, encourage gender mainstreaming in environmental policies and programmes, assess the effects of environmental policies on women and further integrate gender equality and environmental considerations into the work of environmental ministries, UNEP and other United Nations agencies. ${ }^{121}$ This decision can serve as an important guideline for states in addressing the negative impact of environmental hazards on women.

Given the fact that women are likely to be more adversely affected by the impact of oil exploitation activities in the Niger Delta, it is important for policy-makers to address their health issues when developing regulatory frameworks regarding oil exploitation in Nigeria. This may involve ensuring that they have a say in decisions relating to environmental oil exploitation and be adequately compensated whenever they are adversely affected. Also, since women are closer to nature than their male counterparts, they are more intimately attuned to the conservation and preservation of natural resources and so have wider experience and knowledge in ecological processes. ${ }^{122}$ Their relationship with nature has made them experts in matters of local preservation of the environment and ecology. It has given them a better understanding of the local systems and processes than those in government, international development agencies and NGOs, who rely on the generalised principles of ecology to guide policies that are hardly ever sensitive to local realities, thus leading to ineffective results. ${ }^{123}$ Involving women as stakeholders in the Niger Delta issues will help to provide a platform for them to effectively express themselves and make known the various oil exploration activities that adversely affect them which they have so far had no means of voicing. It will also give the government and the MNCs the opportunity to benefit from the enormous wealth and expertise of women, which will go a long way to resolving the environmental crisis in the region and protecting the health of women.

Development efforts that enhance gender equality and women's equal participation as decision-makers in sustainable development were promoted by the Canadian International Development Agency (CIDA). ${ }^{124}$ In this regard, the Canadian government supports the involvement of indigenous women as part of their efforts to meet their commitment under the Convention on Biodiversity. Also, countries like El Salvador, Mexico and some of the Central American countries have recognised that gender equality and equity are essential parts of human rights and social justice and are fundamental for sustainable development and conservation of resources. ${ }^{125}$ The Nigerian government could follow the example shown by these countries by enhancing gender equality and women's equal participation in matters of the environment.

\section{http://repository.uwc.ac.za}


(iv) Strengthening of civil society and NGOs: There is a need to strengthen civil society, environmental NGOs and women's organisations that are active in the area of gender and environment as they are capable of playing a great role in promoting women's participation in environmental issues. Women in the Niger Delta have some time engaged in the struggle against injustice at the hands of the Nigerian government and the oil MNCs. In doing so, they have formed various organisations, including the Niger Delta Women for Justice (NDWJ), the Federation of Ogoni Women's Organizations (FOWO), the Ijaw Women's Organization for Human Rights, and so on, and have been at the forefront in the struggle for equity and justice. It is on record that civil society organisations (CSOs) in Nigeria have played a significant role in female empowerment at different levels, drawing inspiration from the various conventions and treaties ratified by Nigeria. In addition, they are deeply involved in seeing that international and national leaders are accountable for the commitments they made to the Convention on the Elimination of all Forms of Discrimination Against Women (CEDAW) ${ }^{126}$ and its Optional Protocol adopted in 1999, the Beijing Platform for Action, the African Plan of Action and the Beijing +5 Outcome Documents, all of which are important in the protection of the rights of women in Niger Delta. Cooperation with and support of civil society groups and NGOs by the Nigerian government promotes women's leadership in environmental matters and enhances gender equality ${ }^{127} \mathrm{In}$ view of the government's failure to provide adequate protection to the victims of sexual violence in the region, if the NGOs and civil society are empowered, they could help to alleviate sexual violence against women in the region and thereby guarantee a better quality of health for the women of the Niger Delta.

The NGOs could also assist in raising the profile of health issues involved in the exploitation of natural resources, carrying out environmental educational and research activities, raising awareness regarding the enforcement of environmental laws, as well as lobbying the government and the international community. ${ }^{128}$ The Nigerian government created the Federal Ministry of Women Affairs and Youth Development in 1999 from the Federal Ministry of Women Affairs and Social Development established in 1995. And in April 2004, the Youth Development Department was moved to the Presidency, leaving it with the name Federal Ministry of Women Affairs. The aim of the ministry is to advance the cause of Nigerian women and children, and it is thus responsible for the formulation of policy guidelines, programme planning and execution and the provision of specialised services related to the needs and aspirations of Nigerian women and children. ${ }^{129}$ Indeed, the ministry is the main source for operationalising gender mainstreaming, which is one of the strategies for achieving the national development goals of gender equality and equity. ${ }^{130}$ In order to be able to carry out its mandate, the States Ministry of Women Affairs were created in the 36 states of the Federation, with a Women's Department in the Federal Capital Territory (FCT), Abuja. Even though the ministry has on a few occasions criticised actions that damaged the environment, it has not done much regarding the protection of the women of the Niger Delta against the negative impacts of oil exploration activities. The ministry, both at federal and state levels, should be properly funded and have developed the capacity to enable them to

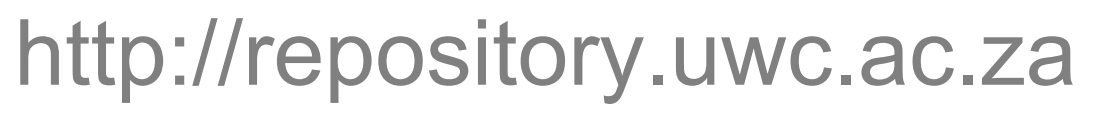


discharge their responsibilities to women, particularly those in the Niger Delta areas and in the rural areas of the country.

(v) Enthronement of good governance: Good governance for sustainable development includes, but not limited to, full and equitable participation of all stakeholders and citizens at all levels of decision-making; government accountability to its citizens; transparency; effectiveness and efficiency, inclusiveness; the rule of law and equality, ${ }^{131}$ which are conditions for ensuring the adequate enforcement of environmental laws and policies. The exclusion of the women of the Niger Delta in matters of the environment, corruption, lack of access to basic necessities of life, like water, health facilities, food, etc., are indications of a failure of governance. In order to ensure the protection of the health and well-being of women and other inhabitants of the region, there is a need for enthronement of good governance, that is, where the rule of law prevails, human security is guaranteed, corruption is treated as an anathema, service delivery is enhanced and women are fully involved in environmental matters. Also, increased action should be taken on the part of the government in addressing the root cause of diseases among women in the region, by ensuring adequate and safe drinking water, good air quality, provision of safe dryers, and so on. These could help to prevent a lot of diseases and a number of deaths per year, particularly among women and children in the region.

\section{Conclusion}

Oil exploitation is essential for the economic growth of Nigeria. However, the irresponsible way in which this is carried out results in serious air, land and water pollution, which subsequently impacts negatively on the health and well-being of the local inhabitants of the Niger Delta, particularly the women, who are often ignored. Thus, rather than be an agent of development and growth, the article contended that oil exploration and production activities in the Niger Delta have become an instrument of oppression, inequity and a means of violating the rights - health, food, water, environment - of the local inhabitants, particularly women, of the region. The article stresses the need to recognise the particular impacts of oil exploration activities on the health of the Niger Delta women, and the vital role that women can play as stewards of natural resources and the environment. The women of the Niger Delta will continue to sacrifice their health and livelihoods for the benefit of the nation and the oil MNCs until they are brought to the forefront of the decision-making structures in matters of the environment. Government must show a strong political will in bringing an end to gas flaring in the Niger Delta. All of this can only be achieved through clear and time bound commitments by the government. If, according to the WHO, about one-third of Africa's disease burden is attributable to environmental hazards ${ }^{132}$ the Nigerian government and the oil MNCs must understand and respond to the oil exploration activities that are negatively impacting the health and livelihood of the women and children in the region. 


\section{Notes}

1. National Bureau of Statistics, Review of the Nigerian Economy in 2011 \& Economic Outlook for 2012-2015 (May 2012), 8, http://www.nigerianstat.gov.ng (accessed July 12, 2012).

2. Uwafiokun Idemudia, 'Assessing Corporate-Community Involvement Strategies in the Nigerian Oil Industry: An Empirical Analysis', Resource Policy 34 (2009): 135.

3. These include the International Covenant on Economic, Social and Cultural Rights, International Covenant on Civil and Political Rights, the Convention on Elimination of All Forms of Discrimination against Women, the Convention on the Rights of the Child, the African Charter on Human and Peoples' Rights and the Protocol to the African Charter on the Rights of Women.

4. Michael Watts, 'Petro-Insurgency or Criminal Syndicate? Conflict, Violence and Political Disorder in the Niger Delta', Niger Delta Economies of Violence Working Paper No. 16, 2008,

http://geography.berkeley.edu/ProjectsResources/ND\%20Website/NigerDelta/WP/16Watts. pdf (accessed August 15, 2012).

5. Chizoba Chinweze, Gwen Abiola-Oloke, and Chike Jideani, 'Energy Resources Management for Sustainable Development in Nigeria Niger Delta Region: Women Issues and the Environment', World Academy of Science, Engineering and Technology 54 (2009): 1167-9, at 1167.

6. Legborsi Saro Pyagbara, 'Shell's Social Licence to Operate: A Case Study of Ogoni', in The Ecumenical Council for Corporate Responsibility (ECCR) Report, Shell in the Niger Delta: A Framework for Change, sponsored by Cordaid, February 2010, 16, http://allafrica.com/download/resource/main/main/idatcs/o0020052:f1951c2ce1554 d231761a0196fbc9b5b.pdf (accessed July 12, 2012).

7. Nenibarini Zabbey, 'Persistent Oil Spillage at Bodo Creek; Unprecedented Impacts on Ecosystem Stability, Biodiversity and Food Security of Ogoni Communities' (report issued by the Environment and Conservation Program, Centre for Environment, Human Rights and Development (CEHRD), Eleme, Rivers State, Nigeria, 2008).

8. Daily Independent, 'Nigeria: The Nation's 3,203 Oil Spills in Four Years', August 2010, http:// allafrica.com/stories/201008130523.html (accessed August 15, 2012).

9. Niger Delta Natural Resource Damage Assessment and Restoration Project May 31, 2006, Report, Federal Ministry of Environment, Abuja, Nigeria Conservation Foundation, WWF UK, CEESP-IUCN Commission on Environmental, Economic, and Social

http://www.ngps.nt.ca/Upload/Interveners/World\%2oWildlife\%20Fund\%20-

\%20Canada/Niger_Delta_scoping_report_2006.pdf (accessed July 12, 2012).

10. UNEP Report on Environmental Assessment of Ogoniland (Nairobi: UNEP, 2011).

11. Ibid.

12. Oil Extraction and Health in the Niger Delta, at 176, http://www.hesperian.info/assets/GHW2/ GHW2_C6.pdf (accessed September 22, 2012).

13. US 'Benze: Teach Chemical Summary', http://www.epa.gov/teach/chem_summ/BENZ_summary.pdfx. 
14. O.S. Olusi, Nigerian Oil Industry and the Environment, Proceedings of the 1981 International Seminar (Lagos, Nigeria: NNPC, 1981).

15. S. Walby, Patriarchy at Work: Patriarchal and Capitalist Relations in Employment (Cambridge: Polity Press, 1986), 50-1, quoted in Susan Buckingham-Hatfield, Gender and Women (London; New York: Routledge, 2003), 6.

16. See Foundation for Partnership Initiatives in the Niger Delta, Gender Assessment in the Niger Delta Region of Nigeria (Abuja: PIN, 2011), 7-10.

17. Heather Goldsworthy, 'Women, Global Environmental Change and Human Security', in Richard A. Matthew, Jon Barnett, Bryan McDonald, and Karen L. O’Brien, Global Environmental Change and Human Security (Cambridge, MA; London: The MIT Press, 2010), 216.

18. Goldsworthy, 'Women, Global Environmental Change and Human Security', 216.

19. C.J. Badenhorst and Anglo Platinum, 'Occupational Health and Safety Considerations for the Employment of Female Workers in Hard Rock Mines' (proceedings of the Southern African Institute of Mining and Metallurgy Hard Rock Safe Safety Conference, 2009), 63.

20. Ibid., 65-8.

21. Ibid., 69.

22. Buckingham-Hatfield, Gender and Women, 7.

23. O. Snapps, 'Dynamic of Poverty Among Niger Delta Women: An Empirical Assessment', American Review of Political Economy (2011): 33-44.

24. E.D. Simon, 'The Niger Delta Region and the Woman's Predicament: A Study of Kaine Agary's Yellow Yellow', African Research Review 4, no. 3b (2010): 158.

25. Kaine Agary, Yellow-Yellow (Lagos: Dtalkshop Publishers, 2006).

26. Ibid.

27. International Covenant on Economic, Social and Cultural Rights, G.A. Res. 2200 (XXI) A, UN Doc. A/6316 at 49 (December 16, 1966).

28. General Comment 12 of the Committee on ICESCR.

29. Ibid.

30. United Nations General Assembly Resolution 45/94.

31. Adopted and opened for signature, ratification and accession by General Assembly Resolution 44/25 of 20 November 1989, and entered into force 2 September 1990, in accordance with Article 49.

32. General Recommendation No. 24 (20th Session, 1999).

33. African [Banjul] Charter on Human and Peoples' Rights, adopted 27 June 1981, OAU Doc. CAB/LEG/67/3 rev. 5, 21 I.L.M. 58 (1982), entered into force 21 October 1986.

34. Social and Economic Rights Action Center (SERAC) and Center for Economic and Social Rights (CESR)/Nigeria, Communication 155/96 (Ogoni's case), paras 52 and 54 of the communication.

35. Ibid., para. 2.

36. Ibid., paras 52 and 54 of the communication.

37. Protocol to the African Charter on Human and Peoples' Rights on the Rights of Women in Africa, adopted by the 2nd Ordinary Session of the Assembly of the Union, 
Maputo, 11 July 2003, and entered into force on 25 November 2005. See Arts 18(1) and (2)(a).

38. Ibid., Art. 19(b).

39. UN Fourth World Conference on Women, Beijing, China - September 1995, Platform for Action, para. 247, http://www.un.org/womenwatch/daw/beijing/platform/environ.htm (accessed July 12, 2012).

40. Agenda 21 of UNCED, Ch. 24 - Global Action for Women towards Sustainable and Equitable Development.

41. World Health Organization/UNICEF, Progress on Sanitation and Drinking-Water, 2010

Update, http://whqlibdoc.who.int/publications/2010/9789241563956_eng_full_text.pdf (accessed July 12, 2012).

42. Paul Francis, Deirdre Lapin and Paula Rossiasco, Securing Development and Peace in the Niger Delta: A Social and Conflict Analysis for Change (study prepared for publication by the Woodrow Wilson International Center for Scholars Africa Program and Project on Leadership and Building State Capacity, Washington, DC, 2011), 10.

43. Elaine Tweneboah, 'Coastal Pollution and Women's Health in Ada-Foah, Ghana', Women and Environments (2003): 16-18, at 17.

44. Human Rights Watch Report, The Price of Oil: Corporate Responsibility and Human Rights Violations in Nigeria's Oil Producing Communities, HRW Index No. 1-56432225-4, (January 1999): 61.

45. Ibid.

46. S. Kretzmann and S. Wright, Human Rights and Environmental Information on the Royal Dutch/Shell Group of Companies, 1996-1997: An Independent Annual Report (San Francisco and Berkeley, CA: Rainforest Action Network and Project Underground, 1997): 6. The EU standard is 0.05 ppm, quoted in Human Rights Watch, The Price of Oil.

47. United Nations Environment Programme, UNEP Environmental Assessment of Ogoniland, Nairobi, Kenya (2011), 127.

48. Dinah Shelton, 'Human Rights and the Environment: What Specific Environmental Rights Have Been Recognized?', Denver Journal of International Law and Policy 35 (2006): $129-71$, at $170-1$.

49. See European Court of Human Rights decision in Tavares v. France App. No. 16593/90 Euro. Comm. HR; see also, the decision of the Inter-American Court in Villagran Marales et al. v. Guatemala Series C No. 65, 19 November 1999(IACHR), para. 144.

50. Earth Rights International, Dead Fish, Dead Trees, No Water to Drink, Fact Sheet, http:// justiceinnigeria.files.wordpress.com/2008/o7/chevron_dead-fish.pdf.

51. Cecile Jackson, 'Environmental Reproduction and Gender in the Third World', in People and Environment, ed. Stephen Morse and Michael Stocking (London: UCL Press Ltd, 1995), 118. This statement is based on the result of a study in a clinic in Bangladesh where $50 \%$ of broken necks were said to have been caused by falls while carrying heavy loads. See V. Curtis, Women and the Transport of Water (London: International Technology Publications, 1986), quoted in ibid. 
52. See Foundation for Partnership Initiatives in the Niger Delta, Gender Assessment in the Niger Delta Region of Nigeria.

53. Institute of Medicine (US) Forum on Microbial Threats, Global Issues in Water, Sanitation, and Health: Workshop Summary, Workshop Overview (Washington, DC: National Academies Press, 2009), http://www.ncbi.nlm.nih.gov/books/NBK28449/.

54. WaterAid, Empowering Women and Girls: How Water, Sanitation and Hygiene Deliver Gender Equality (Addis Ababa: WaterAid, 2012), 3.

55. See Report of UN Independent Expert on Issue of Human Rights Obligations in Relation to Water and Sanitation, 'Human Rights Obligations Related to Access to Safe Drinking Water and Sanitation', UN General Assembly A/65/254.

56. See for instance, Press Statement by the United Nations Special Rapporteur on the Human Right to Safe Drinking Water and Sanitation Ms Catarina de Albuquerque Mission to Tuvalu, http://www.ohchr.org/EN/NewsEvents/Pages/DisplayNews.aspx?NewsID $\quad$ 1/4 12372 \&LangI (accessed January 12, 2013).

57. B.F. Iyun, 'Women's Status, Environmental Changes and Child Health in the Riverine Area of Ondo State, Nigeria', GeoJournal 44, no. 2 (1998): 129-39, at 138.

58. P. Bond and D. Rehana, Trouble in the Air, Global Warming in the Privatised Atmosphere (Durban: Civil Society Reader, 2005), 194.

59. L. Oxburgh, a non-executive chairman of Shell, while responding to an interview on gas flaring in the region, insisted that the locals appreciate the flares as a heat source to dry their fish'. See Restricted Document (1995), Subject My Tel. No: Trial of Ken Saro-Wiwa, February, quoted in Andy Rowell, James Marriot and Lorne Stockman, The Next Gulf: London, Washington and Oil Conflict in Nigeria (London: Constable and Robinson, 2005), 68.

60. The Norwegian Council for Africa, 'Nigeria: Enforcing the Gas Flaring Deadline (Analysis)', Daily Independent (Nigeria), 10 August 2010, http://www.afrika.no/Detailed/19765.html (accessed July 12, 2012).

61. Environmental Rights Action/Friends of the Earth Nigeria and Climate Justice Programme Report, 'Gas Flaring in Nigeria: A Human Rights, Environmental and Economic Monstrosity' (published by Environmental Rights Action/Friends of the Earth Nigeria in collaboration with the Climate Justice Programme, June 2005), 25; See also Miguel San Sebastiá $\mathrm{n}$ and Anna-Karin Hurtig, 'Oil Exploitation in the Amazon Basin of Ecuador: A Public Health Emergency', Rev PanamSaludPublica/Pan American Journal of Public Health 15, no. 3 (2004): 205 - 11, at 208; Jonathan Gay, Olivia Shepherd, Michael Thyden and Matthew Whitman, The Health Effects of Oil Contamination: A Compilation of Research (Worcester Polytechnic Institute), http://www.wpi.edu/Pubs/E-project/Available/E-project-121510203112/unrestricted/Health_Effects_of_Oil_Contamination_-_Final_Report.pdf.

62. A.E. Gobo, G. Richard and I.U Ubong, 'Health Impact of Gas Flares on Igwuruta/Umuechem Communities in Rivers State', Journal of Applied Sciences and Environmental Management 13, no. 3 (2009): 27-33.

63. Ibid., 33 . 
64. Janice E. Nolen, Charlotte Collins, Donald P. Hoppert, Gary Ewart and Rebecca Salay, Re: Oil and Natural Gas Sector: Reviews of New Source Performance Standards and National Emissions Standards for Hazardous Air Pollutants, Docket ID No. EPAHQ-OAR-2010-0505 (being a letter by the American Lung Association, American Public Health Association, American Thoracic Society, Asthma and Allergy Foundation of America Trust for America's Health to Honorable Lisa P. Jackson, Administrator U.S. Environmental Protection Agency EPA Docket Center, Washington, DC, 30 November 2011), http://www.lung.org/get-involved/ advocate/advocacydocuments/air-standards-oil-gas.pdf; Miles Litvinoff, 'Gas Flaring and Health in the Niger Delta', Ecumenical Council for Corporate Responsibility (ECCR), The Bulletin, no. 80 (March 2011): 10-14.

65. M.J. Watts, 'Petro-Violence: Community, Extraction, and Political Ecology' (paper prepared for the Workshop on Environment and Violence, University of California, Berkeley, 24-26 September 1998).

66. Women's Environmental Network, 'Why Women and Climate Change', http://www.wen.org. uk/wp-content/uploads/wen-briefing-net1.pdf (accessed July 12, 2012).

67. Alison Kelly and Richard J. Jackson, 'Public Health Principles and Women's Environmental Health: No More Lost Opportunities', Observations from the CDC, Journal of Women's Health 7, no. 1 (1998): 15-18, at 17.

68. Elaine Tweneboah, 'Coastal Pollution and Women's Health in Ada-Foah, Ghana', Women and Environments (Fall 2003): 16-18, at 17.

69. Quoted in Akosua K. Darkwah, The Impact of Oil and Gas Discovery and Exploration on Communities with Emphasis on Women (National Academy of Sciences, 2003). www.g-rap.org/docs/oil_and_gas/netright-akosua_darkwah-2010.pdf.

70. San Sebastiá n and Karin Hurtig, 'Oil Exploitation in the Amazon Basin of Ecuador', 208.

71. United Nations Conference on Trade and Development, World Investment Report: Transnational Corporations, Extractive Industries and Development (Geneva: United Nations, 2007), 151.

72. Elizabeth May, 'The Environment: A Place to Visit', Women and Environment (Fall 2003): $8-9$, at 8 .

73. Sokari Ekine, 'Women's Responses to State Violence in the Niger Delta', Feminist Africa (2008) 10: 67-83, at 75 .

74. Mrs Kawayorko, quoted in Ibid., at 77.

75. WACOL, A Cry for Justice: The Truth about Sexual Violence against Women in Nigeria (Enugu, Nigeria, 2003), 3, quoted in Amnesty International, 'Nigeria: Rape The Silent Weapon', 28 November 2006, 14.

76. Women Advocates Research and Documentation Centre (WARDC), The 11-Day Siege: Gains and Challenges of Women's Non-Violent Struggles in Niger Delta (Lagos, December 2005), 47, quoted in ibid., at 17-18.

77. Mahima Achuthan and Renee Black, United Nations Security Council Resolution 1820: A Preliminary Assessment of the Challenges and Opportunities, Prepared for the 1820 
Strategy Session International Women's Tribune Centre New York, September 2009, http://www.iwtc. org/182oblog/1820_paper.pdf (accessed July 12, 2012).

78. Alexis Arieff, 'Sexual Violence in African Conflicts', Congressional Research Service, 25 November 2009, http://www.fas.org/sgp/crs/row/R40956.pdf (accessed July 12, 2012).

79. Amnesty International Report, NIGERIA: Time for Justice and Accountability, AI Index: AFR 44/14/oo

http://www.nigerdeltacongress.com/narticles/Nigeria\%20time\%2ofor\% 20justice.htm.

80. Cap. C38 Laws of the Federation of Nigeria (LFN), 2004, sections 357-8, 218, 222.

81. Cap. P3 LFN, 2004, sections 282, 285

82. Adopted by the Second Ordinary Session of the Assembly of the Union, Maputo, 11 July 2003, http://www.achpr.org/english/women/protocolwomen.pdf(accessed July 12, 2012)

83. Ibid., Article 4(2).

84. Ibid., Article 5 .

85. '[T] $]$ he term "torture" means any act by which severe pain or suffering, whether physical or mental, is intentionally inflicted on a person for such purposes as...punishing him for an act he or a third person has committed or is suspected of having committed.. .or for any reason based on discrimination of any kind, when such pain or suffering is inflicted by or at the instigation of or with the consent or acquiescence of a public official or other person acting in an official capacity.' See also Human Rights Watch/Africa, Nigeria: The Ogoni Crisis: A Case Study of Military Repression in Southeastern Nigeria, 1 July 1995, http://www.unhcr.org/refworld/docid/3ae6a7d8c.html(accessed September 22, 2012).

86. International Covenant on Civil and Political Rights, adopted and opened for signature, ratification and accession by General Assembly Resolution 2200A (XXI) of 16 December 1966, entry into force 23 March 1976, in accordance with Article 49. Article 7 thereof provides that: 'No one shall be subjected to torture or to cruel, inhuman or degrading treatment or punishment...'

87. Darkwah, The Impact of Oil and Gas Discovery and Exploration on Communities with Emphasis on Women.

88. Amnesty International, 'Nigeria: Rape - The Silent Weapon', 12.

89. See Ibid., 19.

90. Code of Conduct for Law Enforcement Officials, adopted by General Assembly Resolution 34/ 169 of 17 December 1979. Article 5 thereof provides that: 'No law enforcement official may inflict, instigate or tolerate any act of torture or other cruel, inhuman or degrading treatment or punishment, nor may any law enforcement official invoke superior orders or exceptional circumstances such as a state of war or a threat of war, a threat to national security, internal political instability or any other public emergency as a justification of torture or other cruel, inhuman or degrading treatment or punishment.' Even though the UN Code of Conduct is a non-legally binding instrument, 'the prohibitions on torture and other cruel, inhuman, or degrading treatment have acquired the status of customary international law. As such, the

\section{http://repository.uwc.ac.za}


Nigerian government is legally obligated to uphold them, as well as its treaty commitments'. See Human Rights Watch/Africa, Nigeria: The Ogoni Crisis.

91. Terisa E. Turner and Leigh S. Brownhill, 'The Curse of Nakedness: Nigerian Women in the Oil War', in Feminist Politics, Activism and Vision: Local and Global Challenges, ed. Luciana Ricciutelli, Angela Rose Miles and Margaret McFadden (London: Zed Books, 2005), 9 - 191, at 172, quoted in Darkwah, The Impact of Oil and Gas Discovery and Exploration on Communities with Emphasis on Women.

92. United Nations General Assembly Special Session (UNGASS) Country Progress Report, NIGERIA, National Agency for the Control of AIDS (NACA), Reporting Period: January 2008 - December 2009, March 2010, http://www.unaids.org/en/dataanalysis/monitoringcountryprogress/2010progressrepor tssubmittedbycountries/nigeria_2010_country_progress__report_en.pdf (accessed September 22, 2012).

93. I.A. Udoh, JE Mantell, T Sandfort and MA Eighmy, 'Potential Pathways to HIV/AIDS Transmission in the Niger Delta of Nigeria: Poverty, Migration and Commercial Sex', AIDS Care 21, no. 5 (2009): $567-74$, at 568.

94. Darkwah, The Impact of Oil and Gas Discovery and Exploration on Communities with Emphasis on Women.

95. CEDAW Committee Concluding Observations to Guinea 2001.

96. Concluding Observations of the Committee on CEDAW: Nigeria Forty-First Session, 30 June-18 July 2008 CEDAW/C.NGA/CO/6.

97. Ibid.

98. N.J. Ashton-Jones and O.N. Douglas, Report to Statoil (Nigeria) Ltd.: Baseline Ecological Survey of the Niger Delta, 1994, 29, quoted in K. Ebeku, Oil and the Niger Delta People in International Law: Resource Rights, Environmental and Equity Issues (Germany: Rudiger-KoppeVerlag, 2006), 130.

99. C. Chinwezeand and G. Abiola-Oloke, 'Women Issues, Poverty and Social Challenge of Climate Change in the Nigerian Niger Delta Context' (paper presented at IHDP Open Meeting 2009, the 7th International Conference on the Human Dimension of Global Environmental Change, 26 - 30April, 2009, UN Campus, Bonn, Germany), http://www.openmeeting2009.org/pdf_files/Pdf\% 2opapers/chizoba\%20Chinweze.pdf (accessed July 12, 2012).

100. U. Schippman, Danna Leaman and A.B. Cunningham, 'A Comparison of Cultivation and Wild Collection of Medicinal and Aromatic Plants under Sustainability Aspects', in Medicinal and Aromatic Plants, ed. R.J. Bogers, L.E. Craker and D. Lange (Dordrecht, the Netherlands: Springer, 2006), 75 - 95, quoted in J.A. McNeely and S.A. Mainka, Conservation for a New Era (Gland, Switzerland: International Union for Conservation of Nature and Natural Resources (IUCN), 2009), 94.

101. Michael Baghebo, Ubi Peter Samuel and Eucharia N. Nwagbara, 'Environmental Damage Caused by the Activities of Multinational Oil Giants in the Niger Delta Region of Nigeria', Journal of Humanities and Social Science 5, no. 6 (2012): 9-13 at 12.

102. L.S. Pyagbara, 'The Adverse Impacts of Oil Pollution on the Environment and Wellbeing of a Local Indigenous Community: The Experience of the Ogoni People of Nigeria'

\section{http://repository.uwc.ac.za}


(paper delivered at an International Expert Group meeting on Indigenous Peoples and Protection of the Environment, Russia, 27-29 August 2007.

103. Center for Reproductive Rights and Women Advocacy and Research Development Centre, Broken Promises: Human Rights, Accountability and Maternal Deaths in Nigeria (New York: CRR and WARDC, 2008), 19.

104. Michael Watts and Anna Zalik, 'Africa: The New Frontier for Imperial Oil', http://www.legaloil. com/NewsItem.asp?DocumentIDX1/41147601636\&Category $1 / 4$ news (accessed January 13, 2013).

105. Nnimmo Bassey, 'Oil Politics: The Amnesty Worked', ERA Media Report, 10 December 2010, http://www.eraction.org/media/publications/oil-politics/259-oilpolitics-the-amnesty-worked- (accessed August 10, 2012).

106. Ibid.

107. UNDP Report, Niger Delta Human Development Report 2006, 88, http://hdr.undp.org/en/ reports/nationalreports/africa/nigeria/nigeria_hdr_report.pdf (accessed July 12, 2012).

108. Ibid., 101.

109. May, 'The Environment: A Place to Visit', 9.

110. Amina Salihu, Emem Okon and Ndeye Sow, 'Enhancing the Capacity of Women Leaders of Community Organisations to Contribute Towards Peace Building in the Niger Delta Region of Nigeria', Needs Assessment Report Niger Delta, Nigeria, 12 - 20 (London: International Alert, July 2002).

111. Ibid.

112. Ibid.

113. Federal Ministry of Women Affairs, 'Nigeria's Report on the Implementation of the Beijing Platform for Action and Commonwealth Plan of Action', April 2004, 16, http://www.genderandtrade.org/shared_asp_files/uploadedfiles/911B9951-F8Do-41C58B26- oE717C6CD34B_Nigeria.pdf (accessed July 12, 2012).

114. Women's Environmental Network, 'Why Women and Climate Change', http://www.wen.org. uk/wp-content/uploads/wen-briefing-net1.pdf (accessed September 22, 2012). Of the 16 countries ranked by the United Nations Development Programme that had reduced their overall carbon dioxide emissions between 1990 and 2004, 13 had a higher proportion of female elected representatives than average (14.9\%). See US House of Representatives, 'Representative Offices' (2009), http://www.house.gov/house/MemberWWW_by_State. shtml (accessed July 12, 2012).

115. See, for instance, Gbemre v. Shell Development Company Limited and 2 Others, Unreported Suit no FHC/B/CS53/o5.

116. Ibid.

117. R. Hausmann, L. Tyson and B. Zahidi, Global Gender GAP Report 2012 (Geneva: World Economic Forum, 2012).

118. UNEP, Gender Mainstreaming Among Environmental Ministries, Government Survey (Policy Research Report, World Bank, 2006), 14. 
119. Comfort Hassan, Janice Olawoye and Kent Nnadozie, 'Impact of International Trade and Multinational Corporations on the Environment and Sustainable Livelihoods of Rural Women in Akwa-Ibom State, Niger Delta Region, Nigeria', September 2002, http://depot.gdnet.org/ cms/conference/papers/4th_prl5.5.3_comfort_hassan_paper.pdf (accessed July 12, 2012); Beijing Platform for Action, 1995, para. 79.

120. UNEP GC decision 23/11 (2005).

121. UNEP, Gender Mainstreaming Among Environmental Ministries, 9.

122. Goldsworthy, 'Women, Global Environmental Change and Human Security', 217.

123. Ibid., 232.

124. UNEP, Gender Mainstreaming Among Environmental Ministries, 11. 125.

125. Ibid., $10-11$.

126. This was signed by Nigeria in 1985, and ratified in 1989 .

127. UNEP, Gender Mainstreaming Among Environmental Ministries, 7.

128. International Development Law Organization (IDLO), Strengthening Environmental Law Compliance and Enforcement in Indonesia: Towards Improved Environmental Stringency and Environmental Performance, Issue 6 (Rome: IDLO Research and Publications Unit, 2006), 9.

129. Federal Ministry of Women Affairs, 'Nigeria's Report on the Implementation of the Beijing Platform for Action and Commonwealth Plan of Action', 92.

130. Ibid., 4 .

131. Joan Ross Frankson, Women's Action Agenda for a Healthy and Peaceful Planet 2015, A Decade of Women's Advocacy for Sustainable Development (New York: Women's Environment and Development Organization (WEDO) and Network for Human Development (REDEH), 2002), http://www.generoyambiente.org/arcangel2/documentos/383.pdf (accessed July 12, 2012).

132. Onyemaechi C. Nweke and William H. Sanders III, 'Modern Environmental Health Hazards: A Public Health Issue of Increasing Significance in Africa', Environmental Health Perspectives 117, no. 6 (2009), 863-70, at 863, cited in A. Prü ss-Ü stün and C. Corvalá n, Preventing Disease through Healthy Environments: Towards an Estimate of the Environmental Burden of Disease (Geneva: World Health Organization, 2006). 